Braz J Med Biol Res, January 2012, Volume 45(1) 58-67

doi: 10.1590/S0100-879X2011007500157

Effect of activation of canonical Wnt signaling by the Wnt-3a protein on the susceptibility of PC12 cells to oxidative and apoptotic insults

E.M. Kawamoto, M. Gleichmann, L.M. Yshii, L. de Sá Lima, M.P. Mattson and C. Scavone

The Brazilian Journal of Medical and Biological Research is partially financed by

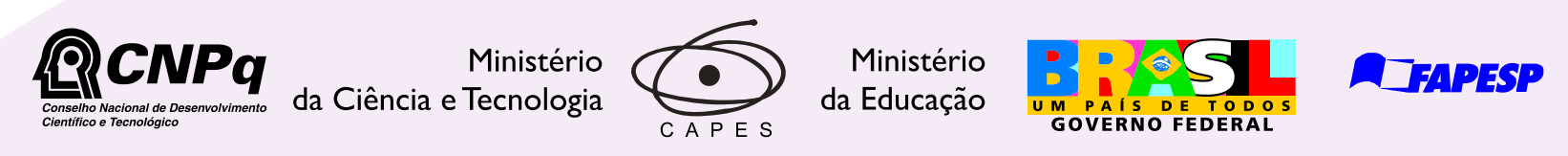

Institutional Sponsors
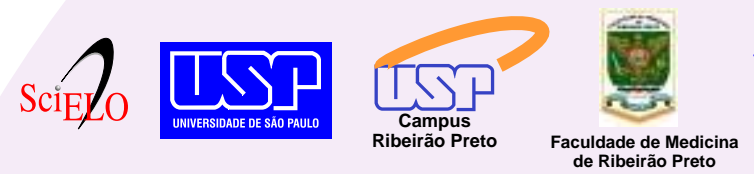
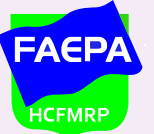

CFMRP UNICAMP

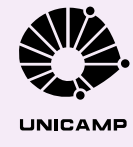

Ф SHIMADZU

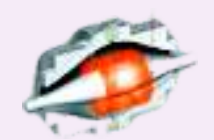

1D Associaçăo Explore High - Performance MS Orbitrap Technology In Proteomics \& Metabolomics analitica Thermo 


\title{
Effect of activation of canonical Wnt signaling by the Wnt-3a protein on the susceptibility of PC12 cells to oxidative and apoptotic insults
}

\author{
E.M. Kawamoto ${ }^{1,2}$, M. Gleichmann², L.M. Yshii ${ }^{1}$, L. de Sá Lima1, \\ M.P. Mattson ${ }^{2}$ and C. Scavone ${ }^{1}$ \\ ${ }^{1}$ Departamento de Farmacologia, Instituto de Ciências Biomédicas, \\ Universidade de São Paulo, São Paulo, SP, Brasil \\ 2Laboratory of Neurosciences, National Institute on Aging Intramural Research Program, \\ Baltimore, MD, USA
}

\begin{abstract}
Wnt proteins are involved in tissue development and their signaling pathways play an important role during embryogenesis. Wnt signaling can promote cell survival, which is beneficial for neurons, but could also lead to tumor development in different tissues. The present study investigated the effects of a Wnt protein on the susceptibility of a neural tumor cell line (PC12 cells) to the cytotoxic compounds ferrous sulfate $(10 \mathrm{mM})$, staurosporine (100 and $500 \mathrm{nM}), 3$-nitropropionic acid $(5 \mathrm{mM})$, and amyloid $\beta$-peptide $\left(A \beta_{25-35} ; 50 \mu \mathrm{M}\right)$. Cells $\left(1 \times 10^{6}\right.$ cells $\left./ \mathrm{mL}\right)$ were treated with the Wnt-3a recombinant peptide $(200 \mathrm{ng} / \mathrm{mL})$ for $24 \mathrm{~h}$ before exposure to toxic insults. The Wnt-3a protein partially protected PC12 cells, with a $6-15 \%$ increase in cell viability in the presence of toxic agents, similar to the effect measured using the MTT and lactate dehydrogenase cell viability assays. The Wnt-3a protein increased protein expression of $\beta$-catenin by $52 \%$ compared to control. These findings suggest that Wnt signaling can protect neural cells against apoptosis induced by toxic agents, which are relevant to the pathogenesis of Alzheimer's and Huntington's diseases.
\end{abstract}

Key words: Wnt-3a; PC12 cells; Beta-catenin; NF-kB

\section{Introduction}

In 1982, Nusse and Varmus (1) identified a protooncogene called Wnt-1 as a signaling molecule involved in breast cancer development. It is now well established that Wnt proteins, which were first studied in Drosophila and Xenopus, are important mediators of intercellular communication and the signaling mediated by these proteins is vital to normal organogenesis in several systems including the central nervous system (CNS) (for reviews, see Refs. 1-3). It has been demonstrated that Wnts regulate several cellular processes including cell proliferation, cell polarity and movement, apoptosis, neuronal circuit development, and neuronal plasticity in adult animals (4).

Wnt proteins can be divided into two classes based on the signaling pathways they activate: canonical Wnts (Wnt-1, Wnt-3a and Wnt-8), which act through $\beta$-catenin, and noncanonical Wnts (Wnt-4, Wnt-5a and Wnt-11), which are not related to $\beta$-catenin, and instead signal via planar cell polarity
(PCP) and calcium (5,6). Wnt proteins bind to receptors called Frizzled (Fz), which are transmembrane proteins (7). So far $19 \mathrm{Wnt}$ genes and $10 \mathrm{Fz}$ genes have been identified in mice. The Wnt-Fz activates a cytosolic protein called Dishevelled (Dvl) (8). Once activated, Dvl can engage three pathways: canonical or Wnt/B-catenin, PCP and Wnt/calcium. Evidence suggests crosstalk among these pathways $(4,9)$.

Activated Dvl inhibits the complex formation by AXIN, adenomatous polyposis coli protein (APC), glycogen syn-

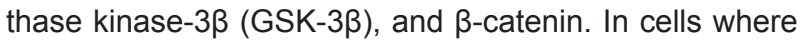
Wnt is not activated, GSK-3 $\beta$ phosphorylates $\beta$-catenin, activating its degradation in the proteasome. On the other hand, Wnt activation causes GSK-3 $\beta$ inhibition that leads to an increase of cytosolic $\beta$-catenin that migrates to the nucleus to form a complex with the T-cell factor (TCF), a transcription factor that regulates many different genes (for a review, see Ref. 10).

Correspondence: C. Scavone, Departamento de Farmacologia, Instituto de Ciências Biomédicas, USP, Avenida Lineu Prestes, 1524, 05508-900 São Paulo, SP, Brasil. Fax: +55-11-3091-7325. E-mail: cristoforo.scavone@gmail.com

Received March 23, 2011. Accepted November 10, 2011. Available online November 25, 2011. Published January $16,2012$. 
Recent findings suggest that Wnt signaling may play a neuroprotective role, for example, protecting cultured hippocampal neurons against amyloid $\beta$-peptide $(A \beta)(11)$. In addition, it has been proposed that a decrease in Wnt activity may play a role in CNS diseases such as schizophrenia (12), retinal neurodegeneration (13), autism (14), and Alzheimer's disease $(15,16)$.

Other evidence has shown the involvement of Wnt signaling in tumor development in humans, especially in colon and liver cancers $(17,18)$. Therefore, a better understanding of the mechanisms by which Wnt signaling affects the susceptibility of cells to toxic insults could be useful in the development of novel interventions for the treatment of neurodegenerative disorders. In the present study, we evaluated the effects of Wnt signaling on the viability of neural cells exposed to an array of cytotoxic compounds including ferrous sulfate, staurosporine, 3-nitropropionic acid, and $A \beta_{25-35}$.

\section{Material and Methods}

\section{Reagents}

Dulbecco's minimum essential medium (DMEM), fetal calf serum, penicillin, and streptomycin were purchased from Cultilab (Brazil). Horse serum was purchased from Invitrogen (USA). $A \beta_{25-35}$ was obtained from Bachem (USA). Wnt-3a was purchased from R\&D Systems (USA) and staurosporine from Tocris (USA). Reagents for SDSPAGE and immunoblotting were purchased from Bio-Rad Laboratories (USA), and ethidium bromide from Promega (USA). Antibody to $\beta$-actin was obtained from Santa Cruz Biotechnology (USA) and antibody to $\beta$-catenin from Cell Signaling (USA). Ferrous sulfate $\left(\mathrm{FeSO}_{4}\right), 3$-nitropropionic (3-NP) acid, 3-[4,5-dimethylthiazol-2-yl]-2,5-diphenyl tetrazolium bromide (MTT), dimethyl sulfoxide (DMSO), and routine reagents were from Sigma-Aldrich (USA). A lactate dehydrogenase (LDH) kit was obtained from Roche Diagnostics (Germany).

\section{PC12 cells}

The PC12 cell line (cells derived from rat pheochromocytoma) was obtained from the American Type Culture Collection, USA. Cells were cultured $\left(1 \times 10^{6} \mathrm{cells} / \mathrm{mL}\right)$ in DMEM plus $10 \%$ horse serum and $5 \%$ fetal calf serum and kept at $37^{\circ} \mathrm{C}$ in a humidified $5 \% \mathrm{CO}_{2}$ atmosphere until $90 \%$ confluence (19).

\section{Treatment of PC12 cell with recombinant Wnt-3a and toxic agents}

$\mathrm{A} \beta_{25-35}$ was diluted in distilled water to $1 \mathrm{mM}$ and kept at $-20^{\circ} \mathrm{C}$ until use. Before use, the peptide was diluted in sterile PBS to $200 \mu \mathrm{M}$ and incubated at $37^{\circ} \mathrm{C}$ for 5 days to allow peptide aggregation (20). $\mathrm{FeSO}_{4}$ was dissolved in water, staurosporine in DMSO and 3-NP acid in ethanol; all these agents were prepared as $1 \mathrm{M}$ stock solutions.
DMSO or ethanol vehicles ( $0.1 \%$ final concentration) were added to control cultures. $A \beta_{25-35}, 50 \mu \mathrm{M}, 10 \mathrm{mM} \mathrm{FeSO}_{4}$, 100 and $500 \mathrm{ng} / \mathrm{mL}$ staurosporine, and $5 \mathrm{mM}$ 3-NP acid were added to the culture medium $24 \mathrm{~h}$ after the addition of mouse recombinant Wnt-3a peptide dissolved in saline at three concentrations $(50,100$, and $200 \mathrm{ng} / \mathrm{mL})$. Cell viability and protein expression by immunoblot were measured $24 \mathrm{~h}$ later. During the treatment period cells were kept in DMEM with $1 \%$ horse serum and $0.5 \%$ fetal calf serum (19).

\section{MTT reduction and LDH release assay}

Cell viability was estimated by the MTT reduction (21), which changes the color of MTT only in the presence of live cells since the ring of the tetrazolium salt is cleaved by several dehydrogenase enzymes present in active mitochondria. After incubation of the cells with Wnt-3a, staurosporine, 3-NP acid and $\mathrm{FeSO}_{4}$ or $\mathrm{A} \beta_{25-35}$ for $24 \mathrm{~h}$, the culture medium was changed, and MTT (final concentration $0.5 \mathrm{mg} / \mathrm{mL}$ ) was added to the cells. Absorbance $(570 \mathrm{~nm})$ was measured after $30 \mathrm{~min}$ in a multiwell plate reader (Bio-Tek Instruments, USA). Results are reported as percent of control values.

Cytotoxicity was also estimated by measuring the release of LDH into the medium (22). After treatment of the cells, the $\mathrm{LDH}$ released in the culture medium was measured using a colorimetric LDH cytotoxicity assay kit (Roche Applied Sciences, USA) according to manufacturer instructions. Briefly, LDH oxidizes lactate to pyruvate with conversion of $\mathrm{NAD}^{+}$to $\mathrm{NADH}$, which reacts with iodonitrotetrazolium to form formazan. The results are reported as percent of control absorbance at $490 \mathrm{~nm}$ measured after 15-20 min in a multiwell plate reader (Bio-Tek Instruments).

\section{Electrophoretic mobility shift assay}

Nuclear extracts were prepared as described previously (23). Briefly, cells were scraped in cold PBS (supplemented with $2 \mu \mathrm{g} / \mathrm{mL}$ leupeptin, $2 \mu \mathrm{g} / \mathrm{mL}$ antipain, and $0.5 \mathrm{mM} \mathrm{PMSF}$ ) and centrifuged at $4^{\circ} \mathrm{C}$ for $2 \mathrm{~min}$ at $13,000 \mathrm{~g}$. Pellets were resuspended in lysis buffer (10 mM HEPES, pH 7.9, $1.5 \mathrm{mM}$ $\mathrm{MgCl}_{2}, 10 \mathrm{mM} \mathrm{KCl}, 0.1 \mathrm{mM}$ EDTA, $0.5 \mathrm{mM}$ PMSF, $2 \mu \mathrm{g} / \mathrm{mL}$ leupeptin, $2 \mu \mathrm{g} / \mathrm{mL}$ antipain, $3 \mathrm{mM}$ sodium orthovanadate, 30 $\mathrm{mM}$ sodium fluoride, and $20 \mathrm{mM}$ sodium pyrophosphate) and incubated on ice for $15 \mathrm{~min}$. After the addition of NP-40 (to a final concentration of $0.5 \%$ ), samples were vigorously mixed and centrifuged for $30 \mathrm{~s}$ at 13,000 g. Supernatants were kept at $-80^{\circ} \mathrm{C}$ for immunoblot analysis. Nuclei were resuspended in extraction buffer (20 mM HEPES, pH 7.9, 25\% glycerol, 1.5 $\mathrm{mM} \mathrm{MgCl}_{2}, 300 \mathrm{mM} \mathrm{NaCl}, 0.25$ mM EDTA, 0.5 mM PMSF, $2 \mu \mathrm{g} / \mathrm{mL}$ leupeptin, and $2 \mu \mathrm{g} / \mathrm{mL}$ antipain), incubated for 20 min on ice, and centrifuged for $20 \mathrm{~min}$ at $13,000 \mathrm{~g}$ at $4^{\circ} \mathrm{C}$. The remaining supernatants containing nuclear proteins were aliquoted and stored at $-80^{\circ} \mathrm{C}$. Protein concentration was determined using the Bio-Rad protein reagent (Bradford).

Electrophoretic mobility shift assay (EMSA) for NF-kB was performed using a gel shift assay kit from Promega. 
NF-kB double-stranded consensus oligonucleotide (5'- AG TTGAGGGGACTTTCCCAGGC-3') was end-labeled with $Y$ '-[32P]-ATP using T4 polynucleotide kinase. Unincorporated nucleotides were removed by passing the reaction mixture through a Sephadex G-25 spin column (Amersham-Pharmacia, Uppsala, Sweden). A purified [ $\left.{ }^{32} \mathrm{P}\right]$-labeled probe $(25,000 \mathrm{cpm})$ was incubated with $5 \mu \mathrm{g}$ nuclear extracts in a $20-\mu \mathrm{L}$ binding reaction mixture containing $50 \mathrm{mM} \mathrm{NaCl}, 0.2$ mM EDTA, $0.5 \mathrm{mM}$ DTT, $4 \%$ glycerol, $10 \mathrm{mM}$ Tris- $\mathrm{HCl}$, $\mathrm{pH}$ 7.5 , and $0.05 \mu \mathrm{g}$ poly (dl-dC) for $30 \mathrm{~min}$ at room temperature. DNA-protein complexes were separated by electrophoresis on a $6 \%$ nondenaturing acrylamide:bis-acrylamide (37.5:1) gel in 0.53 Tris-borate/EDTA (TBE) for $2 \mathrm{~h}$ at $150 \mathrm{~V}$. Gels were vacuum-dried and analyzed by autoradiography.

For competition experiments, unlabeled double-stranded consensus NF-KB oligonucleotide was included in 2.5- to 10 -fold molar excess over the amount of the [ $\left.{ }^{32} \mathrm{P}\right]-\mathrm{NF}-\mathrm{kB}$ probe to detect specific and nonspecific DNA-protein interactions. Unlabeled oligonucleotides were added to the reaction mixture 20 min before the radioactive probe. The composition of the complexes was determined by supershift assays; antibodies (1:10 dilution) against p50 and p65 NF-KB subunits were added before the incubation of nuclear extracts with the labeled oligonucleotide. Autoradiographs were quantified with the Chemlmager detection system (Alpha-Innotech Corporation, USA), and several exposure times were analyzed to ensure linearity of the band intensities.

\section{Immunoblot analyses}

Electrophoresis was performed using a Bio-Rad miniProtean III apparatus. Briefly, the proteins present in the cytosolic $(10 \mu \mathrm{g})$ fraction were size-separated by SDSPAGE (10\% acrylamide). The proteins were blotted onto a nitrocellulose membrane (Bio-Rad) and incubated with the $\beta$-catenin antibody. The Ponceau-staining method was used to control for differences in protein loading (24). Proteins recognized by antibodies were developed by the ECL technique, following manufacturer instructions (Amersham, USA). A Chemlmager detection system (Alpha-Innotech Corporation) was used to standardize and quantify the immunoblots. Several exposure times were analyzed to ensure the linearity of the band intensities. $\beta$-actin antibody was used as an internal control. Data are reported in relation to the intensity of the $\beta$-actin band.

\section{Measurement of Frizzled mRNA levels by RT-PCR}

Total RNA was isolated using the Trizol reagent (Invitrogen) according to manufacturer instructions. Semiquantitative reverse transcription-PCR (RT-PCR) amplification was performed using the ThermoScript RT kit (Invitrogen) according to manufacturer instructions. The primer sequences were: Fz 1 (170 bp), 5'-GCC AAG CCT AGT CAC TCC AG-3' (sense) and 5'-TAG TAT CGG AGC GAG GGC TA-3' (antisense); Fz 2 (287 bp), 5'-CCT GGA GGT GCA TCA ATT CT-3' (sense) and 5'-GGT GAG TAG CGC AGG
AGT TC-3' (antisense); Fz 3 (167 bp), 5'-GAA GCA AAG CAG GGA GTG TC-3' (sense) and 5'-GAG TGA TCT GTC AGC CGT GA-3' (antisense); Fz 4 (110 bp), 5'-AGC TGA CTG GCC TGT GCT AT-3' (sense) and 5'-CAA GCC TGC AGCAAT GAATA-3' (antisense); Fz 5 (275 bp), 5'-TGT GCA CAG TCG TCT TCC TC-3' (sense) and 5'-CCA AGA CAA AGC CTC GTA GC-3' (antisense); Fz 6 (164 bp), 5'-TGT TGG GCT GTC TCT CCT CT-3' (sense) and 5'-GCC AAG AAG CGT CAC TAA GG-3' (antisense); Fz 7 (268 bp), 5'TCT GGG TAG GTG TGT GGT CA-3' (sense) and 5'-AAG CAC CAT GAA GAG GAT GG-3' (antisense); Fz 8 (154 bp), 5'-TCC GTT CAG TCA TCAAGCAG-3'(sense) and 5'-CGG TTG TGC TGC TCA TAG AA-3'(antisense); Fz 9 (105 bp) 5'-AAG TCCATG TTGAGG CGT TC-3' (sense) and 5'-GAA GCT GGA GAA GCT CAT GG-3' (antisense), and Fz 10 (190 bp) 5'-CAA GAC ACC TGA CTG CCT GA-3' (sense) and 5'-TTC CCA AGG TGA GGT TTT TG-3' (antisense). The PCR conditions were $5 \mathrm{~min}$ at $94^{\circ} \mathrm{C}, 35$ cycles of $94^{\circ} \mathrm{C}$ for $45 \mathrm{~s}, 55^{\circ} \mathrm{C}$ for $45 \mathrm{~s}$ and $72^{\circ} \mathrm{C}$ for $90 \mathrm{~s}$ and a final extension at $72^{\circ} \mathrm{C}$ for $10 \mathrm{~min}$. Gel electrophoresis of the PCR product was performed using an ethidium bromide-containing agarose gel (2\%), and the resulting bands were visualized under UV light. The photographs were obtained with a Vilber Lourmat system (Alpha-Innotech Corporation).

\section{Statistical analysis}

Data are reported as means \pm SEM for the indicated number of experiments. Statistical comparisons were performed by the unpaired $t$-test, or one-way ANOVA followed by the Newman-Keuls test $(P<0.05$ was considered to be as statistically significant). All analyses were performed using a Prism4 software package (GraphPad Software, USA).

\section{Results}

Regular RT-PCR was used to evaluate which Fz receptors are expressed in non-differentiated PC12 cells. This cell line expressed mRNA of Fz receptors 1 to 7 , but not 8 , 9, or 10 (Figure 1). Mouse recombinant Wnt-3a protein increased

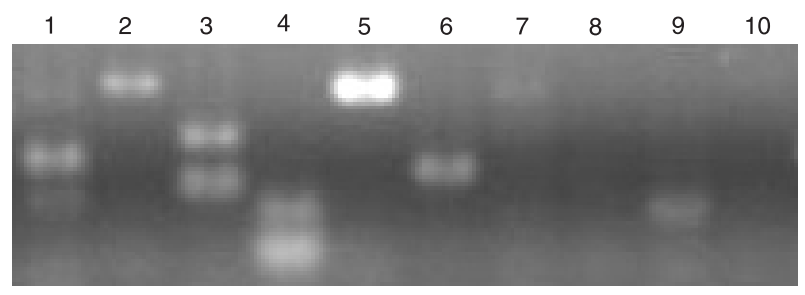

Figure 1. mRNA expression of Frizzled (Fz) receptors (1-10) in PC12 cells by regular RT-PCR. Gel electrophoresis of the PCR product was performed using a $2 \%$ ethidium bromide-containing agarose gel and the resulting bands were visualized under UV light. lane 1: Fz receptor 1; lane 2: Fz receptor 2; lane 3: Fz receptor 3; lane 4: Fz receptor 4; lane 5: Fz receptor 5; lane 6: Fz receptor 6; lane 7: Fz receptor 7; lane 8: Fz receptor 8; lane 9: Fz receptor 9; lane 10: Fz receptor 10. 
the protein levels of $\beta$-catenin in PC12 cells, indicating the presence of the Wnt canonical signaling pathway (Figure 2). The results of densitometric analyses of the immunoblot are shown. The results of the MTT reduction (control $=0.56$ \pm 0.005 ; Wnt-3a $=0.61 \pm 0.02)$ and LDH release (control $=$ $0.58 \pm 0.01$; Wnt $-3 a=0.56 \pm 0.02$ ) assays showed that the concentration of $100 \mathrm{ng} / \mathrm{mL}$ Wnt-3a protein was not toxic to the PC12 cells $(P<0.05$, unpaired Student $t$-test).

In addition, at the same concentration, the Wnt-3a protein prevented about $10 \%$ of the cell damage induced by staurosporine at two toxic concentrations (100 and 500 $\mathrm{nM}$; Figure $3 \mathrm{~A}, \mathrm{~B})$. To evaluate the concentration-response effect of Wnt-3a against the toxic effect of the higher (500 $\mathrm{nM}$ ) concentration of staurosporine, three concentrations of this protein were tested $(50,100$, and $200 \mathrm{ng} / \mathrm{mL})$. The results showed that the low Wnt-3a concentration prevented about $6.5 \%$ of the cell damage, while the concentrations of 100 and $200 \mathrm{ng} / \mathrm{mL}$ were able to induce a significant increase $(10-15 \%)$ in the protection of PC12 cells against this toxic compound (Figure 3C,D). Based on these results that showed no difference in the effect induced by 100 and $200 \mathrm{ng} / \mathrm{mL}$ Wnt-3a peptide, the concentration of $100 \mathrm{ng} / \mathrm{mL}$ was used in all subsequent experiments (Figure 3C,D). A similar result was obtained when cells were incubated with $10 \mathrm{mM} \mathrm{FeSO}_{4}$, since the toxic effect of this compound on PC12 cells was prevented by $100 \mathrm{ng} / \mathrm{mL}$ Wnt-3a, yielding about $10 \%$ protection of cells from iron toxicity (Figure 4 ).

When PC12 cells were incubated with 3-NP acid, $75 \%$ of the cells died. Wnt-3a (100 ng/mL) prevented about $7 \%$ of the cell toxicity caused by 3 -NP acid (Figure 5 ). A higher concentration of Wnt-3a (200 ng/mL) protected about $9 \%$ of the cells against 3-NP acid toxicity, but the effect was not significantly different from the dose of 100 $\mathrm{ng} / \mathrm{mL}$ (Figure 5).

$A \beta_{25-35}$ was toxic to the $P C 12$ cells at a concentration of $50 \mu \mathrm{M}$, and Wnt-3a (100 ng/mL) was able to prevent $10 \%$ of the cell death (Figure 6 ).

EMSAs were performed to study the effects of the Wnt-3a protein in the absence or presence of two toxic agents (staurosporine and $\mathrm{FeSO}_{4}$ ) on NF-kB-binding activity in PC12 cells. Staurosporine (500 nM) and $10 \mathrm{mM}$ $\mathrm{FeSO}_{4}$ reduced the basal levels of NF-KB DNA-binding activity (Figure $7 A, B$ ). The pre-incubation of PC12 cells with Wnt-3a partially reversed this effect since this protein activated NF-KB DNA-binding activity when compared to the activity obtained in cells exposed to staurosporine or $\mathrm{FeSO}_{4}$ alone.

Cell nuclear extracts presented a similar pattern of the DNA-NF-kB protein complex. The complex was displaced by an excess of unlabeled NF-KB, demonstrating the specificity of NF-KB-DNA interaction (Figure 7C). Supershift analysis indicated that the antibody against the p65 subunit was able to shift the DNA-protein interaction observed in the complex. In addition, the antibody against the p50 subunit was also able to shift the NF-kB/DNA complex (Figure

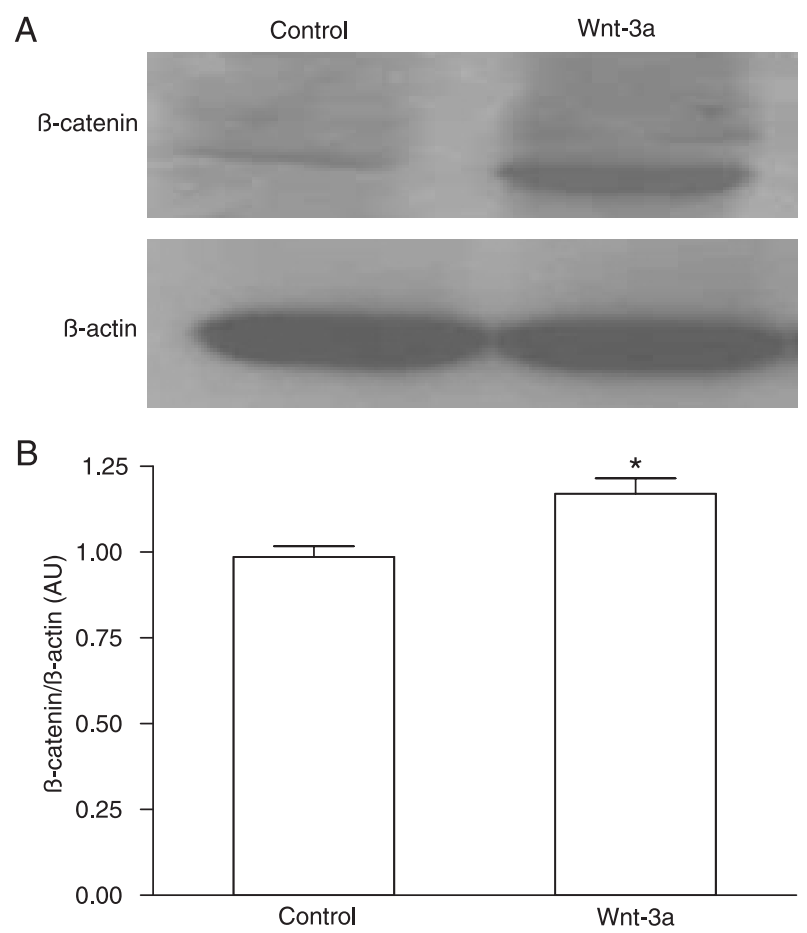

Figure 2. Effects of Wnt-3a (100 ng/mL) on $\beta$-catenin expression by immunoblot assay. $A, A$ representative immunoblot shows increased $\beta$-catenin expression in PC12 cells incubated with Wnt3 a recombinant peptide. $\beta$-actin was used as internal control. $B$, The respective densitometric analyses (arbitrary units, AU) of the $\beta$-catenin/ $\beta$-actin ratio bands presented in Panel $A$ is shown. Data are reported as means \pm SEM for 5 independent experiments. * $P$ $<0.02$ compared to control (unpaired Student $t$-test).

7D). The presence of antibodies against the p52 and c-rel subunits did not affect the DNA-protein complex (data not shown). Therefore, taken together, these results suggest that $\mathrm{p50/p65}$ heterodimers were included in NF-kB protein complexes.

Finally, the effect of Wnt-3a in the presence or absence of staurosporine and $\mathrm{FeSO}_{4}$ on the expression of $\beta$-catenin protein was evaluated in PC12 cells by immunoblot. Exposure of the cells to staurosporine and $\mathrm{FeSO}_{4}$ caused a decrease in $\beta$-catenin protein levels compared to control cultures. In addition, data revealed that when the cells were pre-incubated with Wnt-3a and then exposed to staurosporine or $\mathrm{FeSO}_{4}, \beta$-catenin protein expression increased compared to the cells treated with toxic agents alone (Figure 8).

\section{Discussion}

Fz has been known to function as a Wnt receptor. Although 10 isoforms of Fz receptors have been identified in mammals, their binding specificities with Wnt and functions are poorly understood. Here, we demonstrated that 

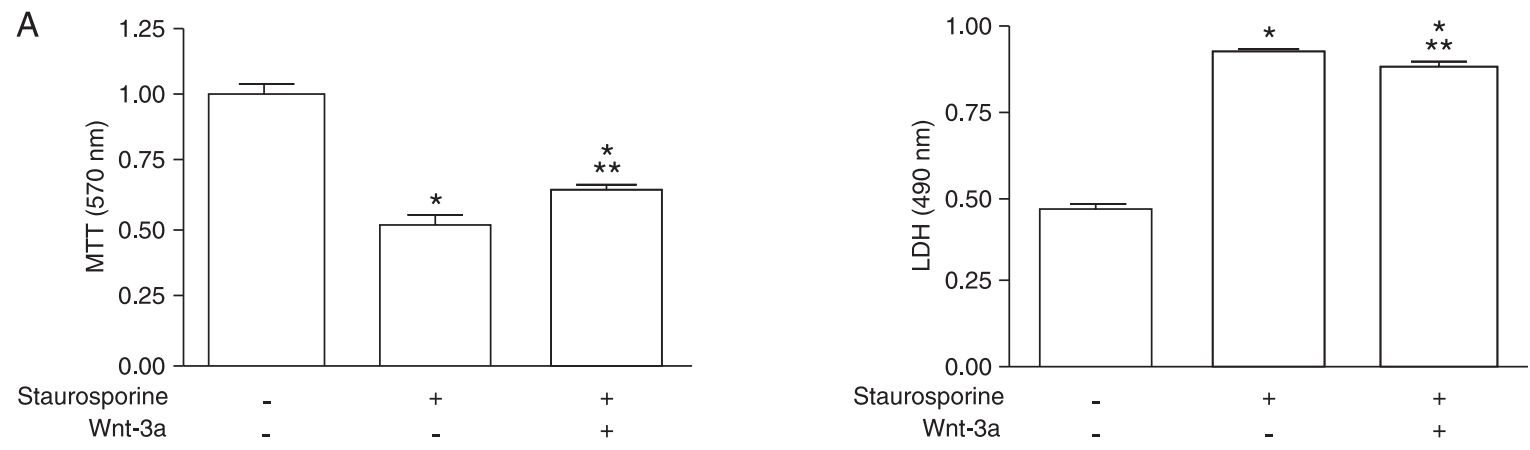

B
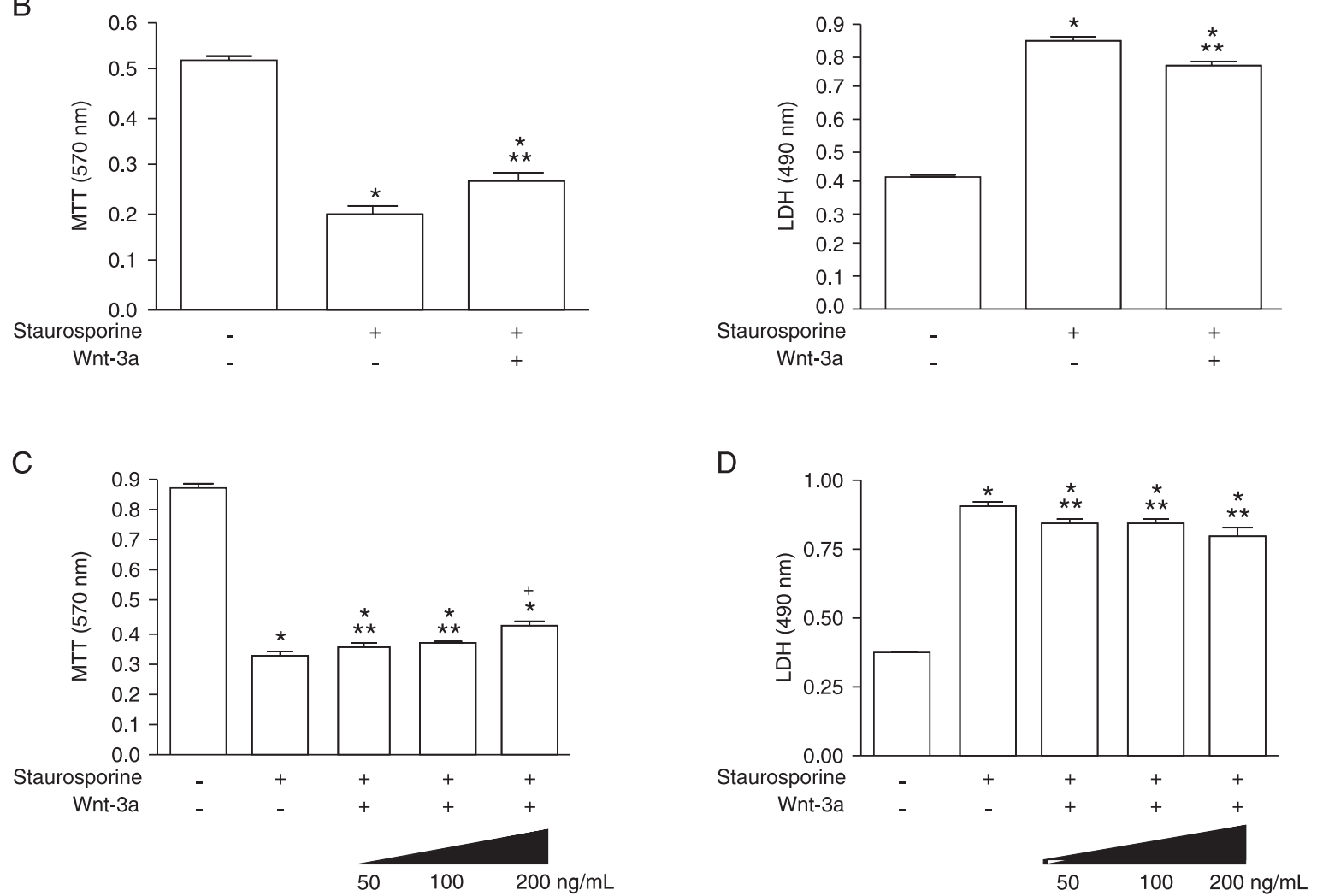

Figure 3. Wnt-3a peptide reduced the loss of cell viability induced by staurosporine. $A, B, \mathrm{PC} 12$ cells were incubated with $100 \mathrm{nM}(A)$ and $500 \mathrm{nM}(B)$ staurosporine $24 \mathrm{~h}$ after the addition of mouse recombinant Wnt-3a peptide $(100 \mathrm{ng} / \mathrm{mL})$. C, D, PC12 cells were incubated with $500 \mathrm{nM}$ staurosporine $24 \mathrm{~h}$ after the addition of three different concentrations of mouse recombinant Wnt-3a peptide (50, 100 , and $200 \mathrm{ng} / \mathrm{mL}$ ). Twenty-four hours later, cell viability was measured by MTT and lactate dehydrogenase (LDH). Data are reported as means \pm SEM for 6 independent experiments. ${ }^{*} \mathrm{P}<0.001 \mathrm{vs}$ control (vehicle: $0.08 \%$ DMSO); ${ }^{* *} \mathrm{P}<0.05$ vs staurosporine; ${ }^{+} \mathrm{P}<0.05$ vs staurosporine $+50 \mathrm{ng} / \mathrm{mL}$ Wnt or staurosporine $+100 \mathrm{ng} / \mathrm{mL}$ WNT (one-way ANOVA followed by the Newman-Keuls test).

PC12 cells express most of the Fz receptors, except Fz 8, 9 , and 10 , which is in accordance with a previous study in which Wnt signaling was observed in PC12 cells (25). Fz receptors seem to have a functional role in $\mathrm{PC} 12$ cells since their activation by Wnt-3a recombinant protein induced an increase in $\beta$-catenin expression.

When discovered, the Wnt protein was associated with tumors in vertebrates. Wnt signaling pathways are now well known for their involvement in tumor development in humans, especially in colon and liver cancers 
A

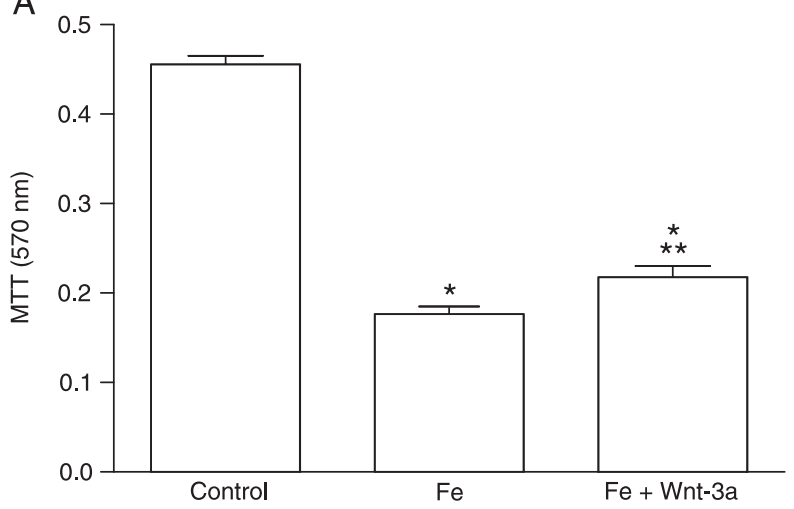

B

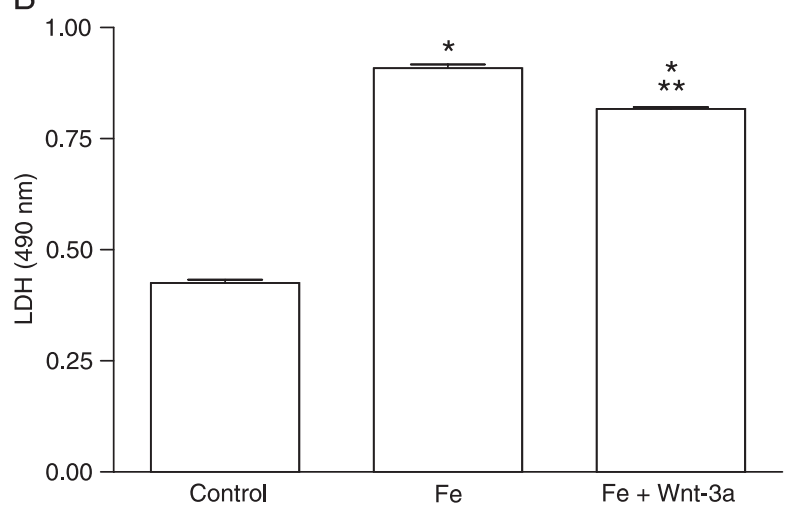

Figure 4. Wnt-3a peptide reduced the loss of cell viability induced by $10 \mathrm{mM} \mathrm{FeSO}_{4}(\mathrm{Fe})$. A, $B, \mathrm{PC} 12$ cells were incubated with $10 \mathrm{mM}$ $\mathrm{FeSO}_{4} 24 \mathrm{~h}$ after the addition of mouse recombinant Wnt-3a peptide $(100 \mathrm{ng} / \mathrm{mL})$. Twenty-four hours later, cell viability was measured by $A$, MTT reduction $(570 \mathrm{~nm})$ and $B$, by lactate dehydrogenase $(\mathrm{LDH})$ release $(490 \mathrm{~nm})$. Data are reported as means \pm SEM for 6 independent experiments. ${ }^{*} \mathrm{P}<0.001 \mathrm{vs}$ control (vehicle: water); ${ }^{* *} \mathrm{P}<0.05$ vs Fe (one-way ANOVA followed by the Newman-Keuls test).
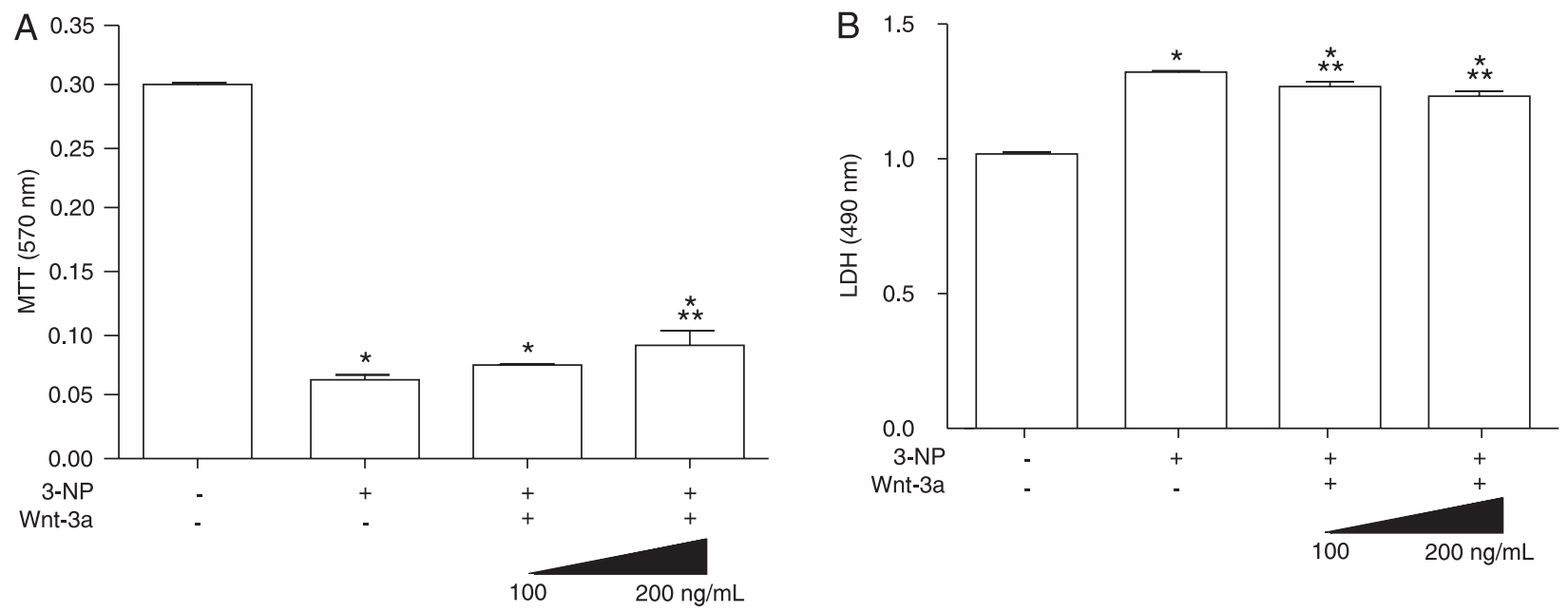

Figure 5. Effect of two concentrations of Wnt-3a peptide against 3-nitropropionic acid (3-NP) toxicity. PC12 cells were incubated with Wnt-3a (100 or $200 \mathrm{ng} / \mathrm{mL}$ ) for $24 \mathrm{~h}$ followed by incubation with $5 \mathrm{mM}$ 3-NP for $24 \mathrm{~h}$. Twenty-four hours later, cell viability was measured by $A$, MTT reduction $(570 \mathrm{~nm})$ and by $B$, lactate dehydrogenase $(\mathrm{LDH})$ release $(490 \mathrm{~nm})$. Data are reported as means \pm SEM for 6 independent experiments. ${ }^{*} \mathrm{P}<0.001 \mathrm{vs}$ control (vehicle: $0.08 \%$ ethanol), ${ }^{* *} \mathrm{P}<0.05$ vs 3 -NP (one-way ANOVA followed by the Newman-Keuls test)
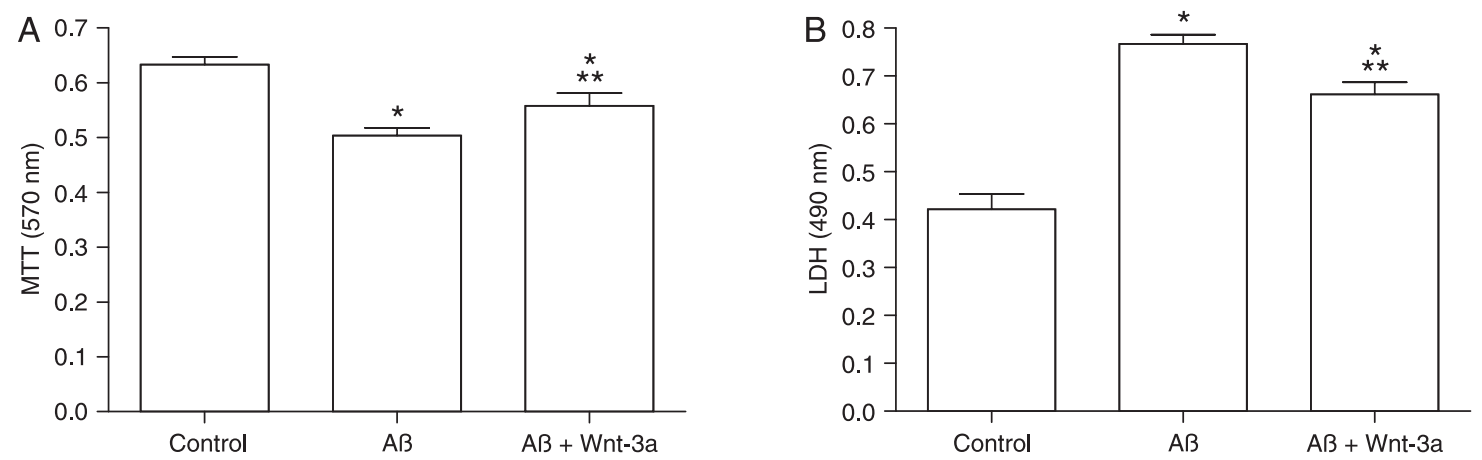

Figure 6. Effect of recombinant Wnt-3a protein on loss of cell viability induced by $A \beta_{25-35}$. PC12 cells were incubated with Wnt-3a (100 $\mathrm{ng} / \mathrm{mL}$ ) for $24 \mathrm{~h}$ followed by $50 \mu \mathrm{M} \mathrm{A} \beta_{25-35}$ for $24 \mathrm{~h}$. Twenty-four hours later, cell viability and protein expression were evaluated by $A$, MTT reduction $(570 \mathrm{~nm})$ and by $B$, lactate dehydrogenase $(\mathrm{LDH})$ release $(490 \mathrm{~nm})$ assays. Data are reported as means \pm SEM for 6 independent experiments. ${ }^{*} \mathrm{P}<0.01$ vs control (vehicle: PBS); ${ }^{* *} \mathrm{P}<0.05$ vs A (one-way ANOVA followed by the Newman-Keuls test). 
A

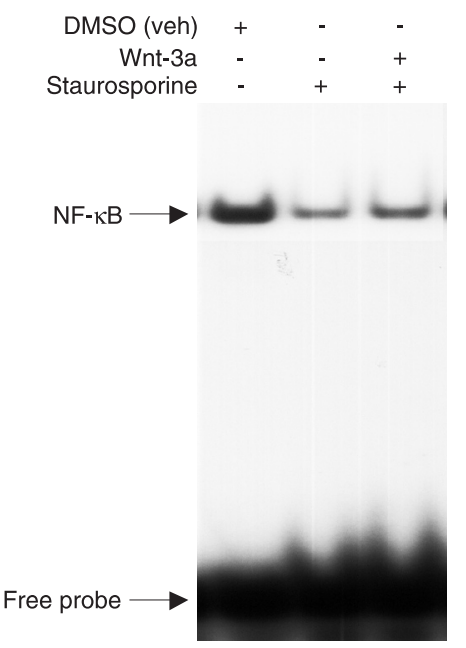

B

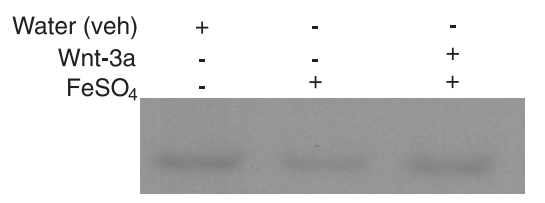

C

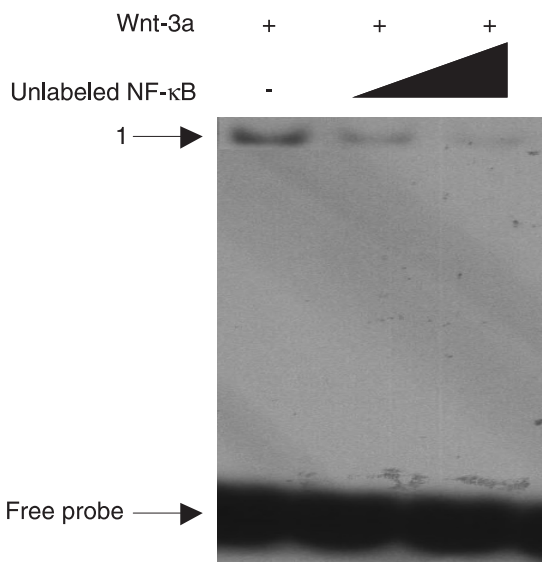

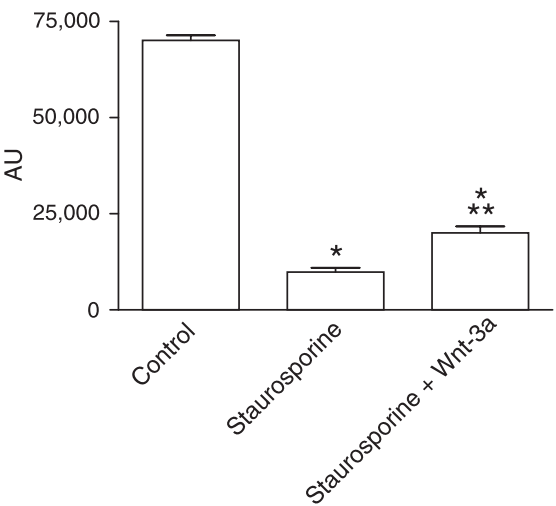

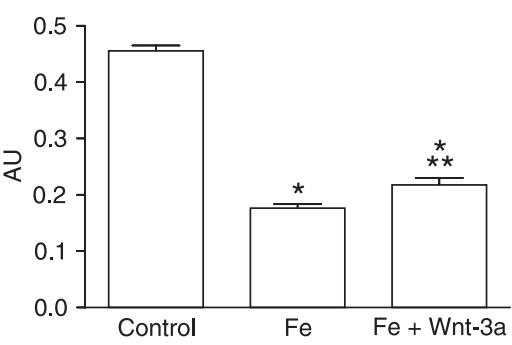

D
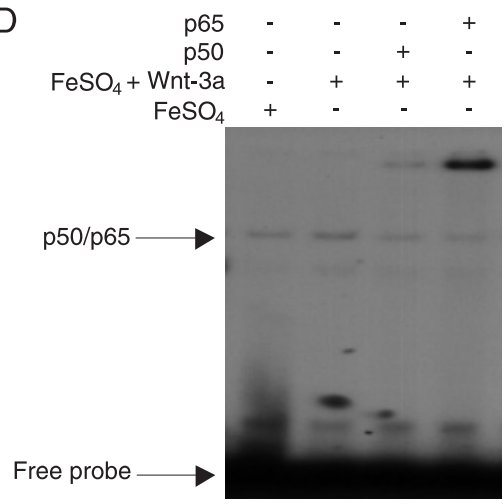

Figure 7. Effect of Wnt-3a on NF-KB suppression induced by staurosporine and $\mathrm{FeSO}_{4}$ on $\mathrm{PC}^{2} 2$ cells. Nuclear proteins $(2.5 \mu \mathrm{g})$ were extracted from PC12 cells pre-incubated $(24 \mathrm{~h})$ with mouse recombinant peptide Wnt3a $(100 \mathrm{ng} / \mathrm{mL})$ followed by $24-\mathrm{h}$ incubation with $A, 500 \mathrm{nM}$ staurosporine or $B, 10 \mathrm{mM} \mathrm{FeSO}_{4}$. Densitometric analyses (arbitrary units, AU) of the NF-KB band are presented in Panels $A$ and $B$. Data are reported as means \pm SEM for 3 independent experiments ${ }^{*} \mathrm{P}<0.001$ vs control; ${ }^{* *} \mathrm{P}<0.05$ vs staurosporine and $\mathrm{FeSO}_{4}$ (one-way ANOVA followed by the Newman-Keuls test). $C$, Competition studies were performed using nuclear extracts (2.5 $\mu \mathrm{g})$ from PC12 cells pre-incubated $(24 \mathrm{~h}$ ) with mouse recombinant protein Wnt-3a $(100 \mathrm{ng} / \mathrm{mL})$ followed by $24-\mathrm{h}$ incubation with saline in the absence and in the presence of unlabeled specific oligonucleotide (2.5- and 10-fold molar excess), as indicated. $D$, Supershift assays were performed with nuclear proteins $(2.5 \mu \mathrm{g})$ extracted from PC12 cells pre-incubated $(24 \mathrm{~h})$ with mouse recombinant peptide Wnt-3a $(100 \mathrm{ng} / \mathrm{mL})$ followed by $24-\mathrm{h}$ incubation with $\mathrm{FeSO}_{4}(10 \mathrm{mM})$ in the absence or presence of antibodies against subunits p50 (1:10 dilution), p65 (1:10 dilution), as indicated. Antibodies were added $20 \mathrm{~min}$ prior to the addition of the radiolabeled NF-kB consensus oligonucleotide. The position of the specific NF-KB/DNA binding complex p50/p65 (band) is indicated. The localization of the probe is also indicated. Results are representative of 3 independent experiments. 
A

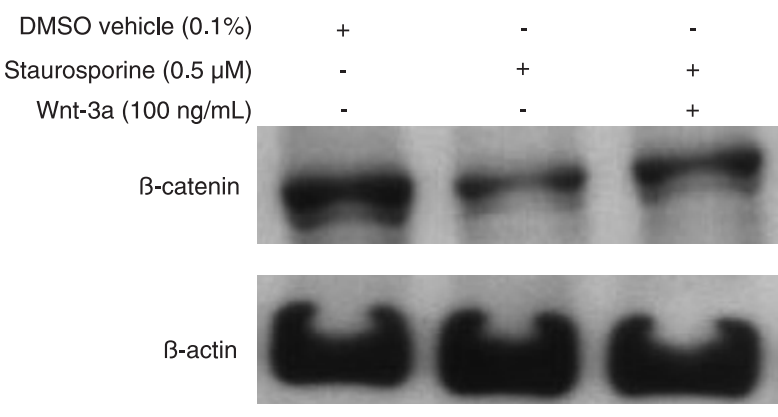

B

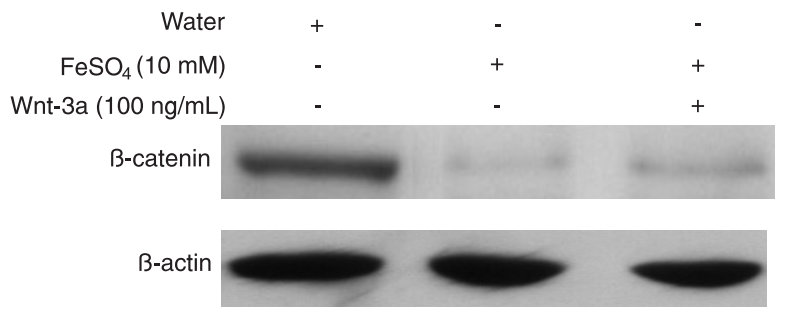

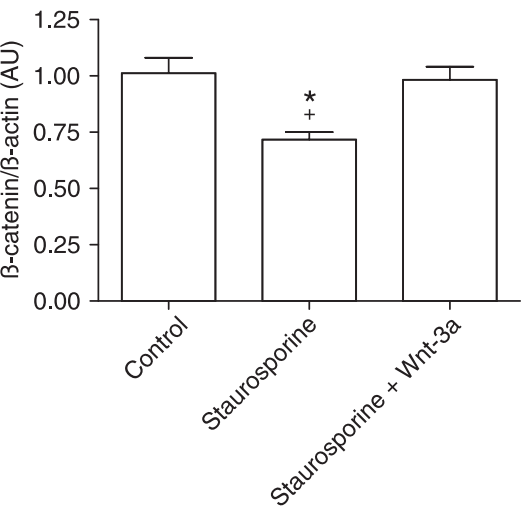

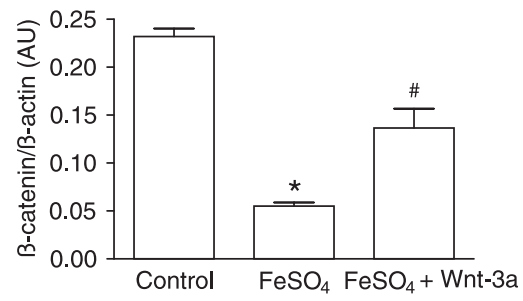

Figure 8. Effect of recombinant Wnt-3a protein on $\beta$-catenin protein suppression induced by staurosporine and $\mathrm{FeSO}_{4}$. $\mathrm{PC}_{12}$ cells were pre-incubated with Wnt-3a recombinant protein $(100 \mathrm{ng} / \mathrm{mL}) 24 \mathrm{~h}$ before treatment with $500 \mathrm{nM}$ staurosporine and $10 \mathrm{mM} \mathrm{FeSO} 4$. Twenty-four hours later, cytosolic proteins $(10 \mu \mathrm{g})$ were isolated and $\beta$-catenin levels were determined by immunoblot. The respective densitometric analyses (arbitrary units, $\mathrm{AU}$ ) of the $\beta$-catenin/ $\beta$-actin ratio bands are presented in Panels $A$ and $B$. Data are reported as means \pm SEM for 3 independent experiments (one-way ANOVA followed by the Newman-Keuls test). ${ }^{*} P<0.05$ vs control; ${ }^{+} P<0.01$ vs staurosporine + Wnt-3a; ${ }^{\#} \mathrm{P}<0.05$ vs control and $\mathrm{FeSO}_{4}$. $\beta$-actin was used as internal control.

$(17,18)$. However, Wnt signaling has recently been linked to diseases related mainly to the CNS, including Alzheimer's disease (26), Parkinson's disease (27), bipolar disorder (28), and schizophrenia (29).

Chong and Maiese (30) demonstrated that overexpression of Wnt-1 in cultured rat primary hippocampal neurons protected the cells against oxidative stress and the toxicity of $A \beta$. In another study, Wnt-3a protected a rat primary neuronal hippocampal culture against $A \beta$ peptide toxicity (11).

Our findings confirm a cytoprotective effect of Wnt-3a against $A \beta$ toxicity, and extend previous observations by demonstrating that activation of the canonical Wnt signaling pathway protects neural cells against a broad range of oxidative and apoptotic insults including exposure to $\mathrm{Fe}^{2+}$, the mitochondrial toxin 3-NP acid, and staurosporine, which triggers mitochondria/caspase-3-mediated apoptosis. These findings shed light on the roles of Wnt signaling in neuroprotection against adverse conditions relevant to the pathogenesis of multiple neurodegenerative disorders.

Previous studies have shown that $\beta$-catenin is proteolytically cleaved during staurosporine-induced apoptosis (31). Here we observed a similar effect since exposure of PC12 cells to staurosporine resulted in decreased $\beta$-catenin expression in PC12 cells as revealed by immunoblot as- say. However, when the cells were pre-treated with Wnt-3a recombinant peptide the amount of $\beta$-catenin was increased compared to the cells treated with staurosporine alone, demonstrating a protective role of Wnt-3a peptide against staurosporine-induced apoptosis. This cytoprotective effect of Wnt-3a was confirmed by MTT reduction and LDH release assays. Staurosporine also decreased NF-KB DNA-binding activity, and the increased activity of this transcription factor in cells pre-incubated with Wnt-3a peptide probably reflects the protective action of this peptide. Indeed, previous studies have shown that activation of NF-KB can protect neurons against death induced by $\mathrm{A} \beta$ (32), $\mathrm{FeSO}_{4}$ (33), and excitotoxicity (34).

An abnormally long polyglutamine or polyalanine tract in different proteins often results in protein aggregation that can be pathological. A well-known example is polyglutamine expansion in the huntingtin protein as the cause of Huntington's disease (HD) (35). It has been demonstrated that lithium can protect against the polyglutamine toxicity of the HD mutation in cell models (36) and in a Drosophila model of HD (37) by inhibiting GSK-3 $\beta$. We observed that 3-NP acid decreased $\beta$-catenin levels in PC12 cells and that pre-incubation of the cells with Wnt-3a peptide increased the $\beta$-catenin level compared to the cells treated with 3-NP acid alone, partially protecting PC12 cells against 3-NP acid 
toxicity. Some studies have also demonstrated that lithium, which activates Wnt signaling pathways, can have a protective action against toxicity in cell models of HD (36).

It has been reported that $A \beta$ causes alterations in the Wnt signaling components, including a reduction of $\beta$-catenin levels in cultured rat hippocampal neurons (11) (38) and GSK-3 $\beta$ activation (39), which could favor tau protein hyperphosphorylation (40). Our findings suggest that Wnt-3a may counteract such adverse effects of $A \beta$ and other oxidative and apoptotic insults. On the other hand, we cannot rule out the possibility that protection induced by Wnt signaling does not involve pathways different from the canonical cascade, which is linked to $\beta$-catenin activation. Based on our results, we suggest that Wnt-3a protein has a protective

\section{References}

1. Nusse R, Varmus HE. Many tumors induced by the mouse mammary tumor virus contain a provirus integrated in the same region of the host genome. Cell 1982; 31: 99-109.

2. Parr BA, McMahon AP. Wnt genes and vertebrate development. Curr Opin Genet Dev 1994; 4: 523-528.

3. Cadigan KM, Nusse R. Wnt signaling: a common theme in animal development. Genes Dev 1997; 11: 3286-3305.

4. Ciani L, Krylova O, Smalley MJ, Dale TC, Salinas PC. A divergent canonical WNT-signaling pathway regulates microtubule dynamics: dishevelled signals locally to stabilize microtubules. J Cell Biol 2004; 164: 243-253.

5. Slusarski DC, Yang-Snyder J, Busa WB, Moon RT. Modulation of embryonic intracellular $\mathrm{Ca}^{2+}$ signaling by Wnt-5A. Dev Biol 1997; 182: 114-120.

6. Tada M, Smith JC. Xwnt11 is a target of Xenopus Brachyury: regulation of gastrulation movements via Dishevelled, but not through the canonical Wnt pathway. Development 2000; 127: 2227-2238.

7. Bhanot $P$, Brink M, Samos $\mathrm{CH}$, Hsieh JC, Wang Y, Macke JP, et al. A new member of the frizzled family from Drosophila functions as a Wingless receptor. Nature 1996; 382: 225230.

8. Wharton KA Jr. Runnin' with the Dvl: proteins that associate with Dsh/Dvl and their significance to Wnt signal transduction. Dev Biol 2003; 253: 1-17.

9. Krylova O, Messenger MJ, Salinas PC. Dishevelled-1 regulates microtubule stability: a new function mediated by glycogen synthase kinase-3beta. J Cell Biol 2000; 151: 8394.

10. Logan CY, Nusse R. The Wnt signaling pathway in development and disease. Annu Rev Cell Dev Biol 2004; 20: 781810.

11. Alvarez AR, Godoy JA, Mullendorff K, Olivares GH, Bronfman M, Inestrosa NC. Wnt-3a overcomes beta-amyloid toxicity in rat hippocampal neurons. Exp Cell Res 2004; 297: 186-196.

12. Miyaoka T, Seno H, Ishino H. Increased expression of Wnt-1 in schizophrenic brains. Schizophr Res 1999; 38: 1-6.

13. Jones SE, Jomary C, Grist J, Stewart HJ, Neal MJ. Modulated expression of secreted frizzled-related proteins in human retinal degeneration. Neuroreport 2000; 11: 3963-3967. effect against different insults including staurosporine, iron, 3 -nitropropionic acid, and amyloid- $\beta$, and possibly against different neurodegenerative diseases.

\section{Acknowledgments}

We thank Maria Aparecida G.S. Fernandes for technical assistance. Research supported by FAPESP (\#06/59722-1 to C. Scavone), CNPq (\#0668-05-2), CAPES, Bunka Fund - Sumitomo Bank, and the National Institute on Aging Intramural Research Program of the NIH. E.M. Kawamoto and C. Scavone were recipients of fellowships from FAPESP and $\mathrm{CNPq}$, respectively.

14. Wassink TH, Piven J, Vieland VJ, Huang J, Swiderski RE, Pietila J, et al. Evidence supporting WNT2 as an autism susceptibility gene. Am J Med Genet 2001; 105: 406-413.

15. Mudher A, Chapman S, Richardson J, Asuni A, Gibb G, Pollard $\mathrm{C}$, et al. Dishevelled regulates the metabolism of amyloid precursor protein via protein kinase $\mathrm{C} /$ mitogen-activated protein kinase and c-Jun terminal kinase. J Neurosci 2001; 21: 4987-4995.

16. De Ferrari GV, Inestrosa NC. Wnt signaling function in Alzheimer's disease. Brain Res Brain Res Rev 2000; 33: 1-12.

17. Peifer M, Polakis P. Wnt signaling in oncogenesis and embryogenesis - a look outside the nucleus. Science 2000; 287: 1606-1609.

18. Polakis $P$, Hart M, Rubinfeld $B$. Defects in the regulation of beta-catenin in colorectal cancer. Adv Exp Med Biol 1999; 470: 23-32.

19. Kruman I, Bruce-Keller AJ, Bredesen D, Waeg G, Mattson MP. Evidence that 4-hydroxynonenal mediates oxidative stress-induced neuronal apoptosis. J Neurosci 1997; 17: 5089-5100.

20. Troy CM, Rabacchi SA, Friedman WJ, Frappier TF, Brown $\mathrm{K}$, Shelanski ML. Caspase-2 mediates neuronal cell death induced by beta-amyloid. J Neurosci 2000; 20: 1386-1392.

21. Mosmann T. Rapid colorimetric assay for cellular growth and survival: application to proliferation and cytotoxicity assays. $\mathrm{J}$ Immunol Methods 1983; 65: 55-63.

22. Decker T, Lohmann-Matthes ML. A quick and simple method for the quantitation of lactate dehydrogenase release in measurements of cellular cytotoxicity and tumor necrosis factor (TNF) activity. J Immunol Methods 1988; 115: 61-69.

23. Rong $Y$, Baudry M. Seizure activity results in a rapid induction of nuclear factor-kappa B in adult but not juvenile rat limbic structures. J Neurochem 1996; 67: 662-668.

24. Salinovich O, Montelaro RC. Reversible staining and peptide mapping of proteins transferred to nitrocellulose after separation by sodium dodecylsulfate-polyacrylamide gel electrophoresis. Anal Biochem 1986; 156: 341-347.

25. Erdreich-Epstein A, Shackleford GM. Differential expression of Wnt genes in normal and flat variants of PC12 cells, a cell line responsive to ectopic Wnt1 expression. Growth Factors 
1998; 15: 149-158.

26. Boonen RA, van Tijn P, Zivkovic D. Wnt signaling in Alzheimer's disease: up or down, that is the question. Ageing Res Rev 2009; 8: 71-82.

27. Sancho RM, Law BM, Harvey K. Mutations in the LRRK2 Roc-COR tandem domain link Parkinson's disease to Wnt signalling pathways. Hum Mol Genet 2009; 18: 3955-3968.

28. Gould TD, Manji HK. The Wnt signaling pathway in bipolar disorder. Neuroscientist 2002; 8: 497-511.

29. Proitsi P, Li T, Hamilton G, Di Forti M, Collier D, Killick R, et al. Positional pathway screen of wnt signaling genes in schizophrenia: association with DKK4. Biol Psychiatry 2008; 63: 13-16.

30. Chong ZZ, Maiese K. Targeting WNT, protein kinase B, and mitochondrial membrane integrity to foster cellular survival in the nervous system. Histol Histopathol 2004; 19: 495-504.

31. Steinhusen U, Badock V, Bauer A, Behrens J, WittmanLiebold B, Dorken B, et al. Apoptosis-induced cleavage of beta-catenin by caspase-3 results in proteolytic fragments with reduced transactivation potential. J Biol Chem 2000; 275: 16345-16353.

32. Barger SW, Horster D, Furukawa K, Goodman Y, Krieglstein $\mathrm{J}$, Mattson MP. Tumor necrosis factors alpha and beta protect neurons against amyloid beta-peptide toxicity: evidence for involvement of a kappa B-binding factor and attenuation of peroxide and $\mathrm{Ca}^{2+}$ accumulation. Proc Natl Acad Sci U S A 1995; 92: 9328-9332.

33. Mattson MP, Goodman Y, Luo H, Fu W, Furukawa K. Activation of NF-kappaB protects hippocampal neurons against oxidative stress-induced apoptosis: evidence for induction of manganese superoxide dismutase and suppression of peroxynitrite production and protein tyrosine nitration. $J$ Neurosci Res 1997; 49: 681-697.

34. Yu Z, Zhou D, Bruce-Keller AJ, Kindy MS, Mattson MP. Lack of the p50 subunit of nuclear factor-kappaB increases the vulnerability of hippocampal neurons to excitotoxic injury. $J$ Neurosci 1999; 19: 8856-8865.

35. Gusella JF, MacDonald ME. Molecular genetics: unmasking polyglutamine triggers in neurodegenerative disease. Nat Rev Neurosci 2000; 1: 109-115.

36. Carmichael J, Sugars KL, Bao YP, Rubinsztein DC. Glycogen synthase kinase-3beta inhibitors prevent cellular polyglutamine toxicity caused by the Huntington's disease mutation. J Biol Chem 2002; 277: 33791-33798.

37. Berger Z, Ravikumar B, Menzies FM, Oroz LG, Underwood $\mathrm{BR}$, Pangalos MN, et al. Rapamycin alleviates toxicity of different aggregate-prone proteins. Hum Mol Genet 2006; 15: 433-442.

38. De Ferrari GV, Chacon MA, Barria MI, Garrido JL, Godoy JA, Olivares G, et al. Activation of Wnt signaling rescues neurodegeneration and behavioral impairments induced by beta-amyloid fibrils. Mol Psychiatry 2003; 8: 195-208.

39. Takashima A, Noguchi K, Sato K, Hoshino T, Imahori K. Tau protein kinase I is essential for amyloid beta-protein-induced neurotoxicity. Proc Natl Acad Sci U S A 1993; 90: 77897793.

40. Takashima A, Murayama M, Murayama O, Kohno T, Honda $\mathrm{T}$, Yasutake K, et al. Presenilin 1 associates with glycogen synthase kinase-3beta and its substrate tau. Proc Natl Acad Sci U S A 1998; 95: 9637-9641. 